\title{
Review and Application of Rule of No Loss and Negation of Distress and Constriction in Iranian Civil Law
}

\author{
Zahra Mohammadi $^{1} \&$ Ali Pourjavaheri ${ }^{1}$ \\ ${ }^{1}$ Department of Law, Islamic Azad University, Yasooj Branch, Yasooj, Iran \\ Correspondence: Zahra Mohammadi, Department of Law, Islamic Azad University, Yasooj Branch, Yasooj, Iran.
}

Received: September 4, 2016

doi:10.5539/jpl.v10n1p91

\author{
Accepted: October 2, 2016 Online Published: December 29, 2016 \\ URL: http://dx.doi.org/10.5539/jpl.v10n1p91
}

\begin{abstract}
Jurisprudential rules are rules that are legislated on the way to gain divine religious commandments, but this use was not in a chapter of inference and mediation, but also it is in chapter of implementation and jurisprudential rules have been used as foundations of many articles legal in Iranian civil law. So considering the importance of these rules, the general aim of this research is investigate frequently used jurisprudential rules in Iranian civil law with an emphasis on (rule of no loss, negation of distress and constriction and beneficence). It should be noted, the rule of no loss, in addition to this that it can limit the circle of preliminary evidences as a secondary reason in personal loss cases, and it suggests overall policy in canonization the initial commandments, so no loss rule has not been used as a documentary, civil liability of compensation for losses. This matter correctly proves that "no loss rule" is as an expression of negation the loss verdict in Islam, not compensation for the losses. Distress and constriction is a general rule that Jurisprudents have referred to it in many cases, and thereby, they have passed a sentence to the negation of tasks which are required the distress and constriction for oblige.

In the chapter of beneficence should also be noted that it includes the disposal of losses and also attracting the interest as well as because the provisions of beneficence rule are rational rules and rational affairs cannot be allocated. So much more certain of the beneficent rule in the legal relationships is where that person was trying to make benefit for others or wants to do the disposal of losses of him/her not to make benefit him/herself. The application of the rule of no loss and negation of distress and constriction is investigated in Iranian civil law in this article.
\end{abstract}

Keywords: jurisprudential rules, rule of no loss, negation of distress and constriction, beneficence, Iranian civil rights

\section{Introduction}

In the days of absence, jurists of Islam have brought out many jurisprudential rules and have provided by inspiring and efficiency of the Islamic resources and texts. Rules that are used sometimes in a chapter, and sometimes they are used in several chapters and sometimes in throughout the jurisprudence. Rules that give the happiness and dynamics to the Jurisprudence and they help to the Jurisprudent in response to new questions. Jurisprudential rules are general provisions that they are a set of homogeneous religious issues and the like, and various chapters are contained in them. In fact, the jurisprudential Rule, is too general formulas that it was the origin of inference of the more limited rules and does not allocate to a specific item, but also includes different and various rules foundations. The Quran and narrations must be considered as the origin of jurisprudential rules. Therefore, it is emphasized that jurisprudential rules are not in the sense of invention and legitimate the rules by Jurisprudents but also in the sense of discovery and gathering them from among religious texts, including the Quran and the traditions of the Infallible Imams (AS) are in their general framework in books that are dedicated to this is among the well-known rules can noted in Muslim lead rule, the rule of no loss, Iodine liability rule, dissipation rule, beneficent rule, confession rule, waiver of the right rule, reservation rule, rule of negation the distress and constriction and like that. These rules help that life becomes easier and social relations are organized better in the faith community and arbitration becomes possible in relation to matters of life and choosing the correct path for most people. Knowing these rules provide this possibility until they can find awareness towards their rights and duties and present appropriate solutions at time of incidence the problems. The aim of this research is investigated and application of civil jurisprudential rules common in Iranian civil law with an emphasis on (rule of no loss, negation of distress and constriction and beneficence). 


\section{Negation Rule of Distress and Constriction}

Distress means being in difficulty, hardship, severity and constriction also mean stricture, narrowness, straitened situation and sin (Hurr Ameli, 1993, vol. 1, p. 327) and the purpose of this rule is that there are not tasks that cause suffering and hardship for oblige in religion in legal and jurisprudential terms (Mousavi Bojnordi, 2003, $\mathrm{v} 1, \mathrm{p} 50)$.

\subsection{Examples of Cases of Distress and Constriction}

Examples of cases of distress and constriction in the family matters in Iranian law, transactions, and rental relations and in international laws are investigated in this article.

\subsubsection{In the Family Matters in Iranian Law}

Article 1130 of the Civil Code has allowed to the wife that requests for divorce by referring to the ruling and judge and proves a distress and constriction state in cases that the continue of married life, makes her in a state of distress and constriction. Being general this article for a woman makes it possible that woman rids herself of the bond of parity, no matter the creating foundation of distress and constriction, by proving the originating cause of hardness and tightness.

2.1.1.1 The Forms of Refusing to Give the Alimony by Husband and Determining the Cases of Distress and Constriction

This issue was discussed earlier in discussing the specific grounds for divorce at the request of the wife, that this case is one of the disobedience cases of husband and a special article is devoted to it in the Civil Code (Article 1129 of civil code) and a woman can go to court in order to claim her right, but in one hand, this case can also be considered as one of the best and obvious examples of distress and constriction. But also with the exception of specific cases that woman can meet independently her life and perhaps her life is not associated with distress and constriction with non-payment of alimony by the husband; and there is a difference that if wife wants to get divorced by reference to Article 1129 of the civil code, merely "disobedient husband" is sufficient, whether wife has properties of herself or not and she is in distress and constriction and adversity, but if she wants to act on the basis of article 1130 of the civil code if the wife is supplied by her own income or by her relatives, she cannot request for divorce despite the lack of alimony of the husband. Because the criteria for divorce is distress and constriction and durability of that on the basis of Article 1130 of the Civil Code that it is negative in the recent case.

\subsubsection{The Husband Refuses to Fulfill the Obligatory Rights of Woman}

It was mentioned that obligatory rights of woman, is a metaphor of specific marriage duties; and in this case, although the woman because of the disobedience of husband can request for divorce, but "refrain the husband from sexual relations with a woman can be known as cases that may cause distress and constriction in certain circumstances. Because regardless of the physical and emotional needs of women, injustice and indifference of her husband is considered as an insult to woman in this regard, and the continuation of married life is unbearable and the woman has the right to ask the court to divorce" (Katoziyan, 1997, 130).

Of course, not doing the marital duty from the side of the husband towards the past time has not enough made force her husband to divorce. But also, it must be proved in court that the husband is not willing to fulfill it later and it would not force him for it because continuing the mentioned situation impairs the marital survival.

Otherwise, if the husband does not fulfill obligatory rights of woman, but he does them now or he is willing to do them later then he cannot be forced to divorce his wife. Another point is that sometimes non-fulfillment of marital duties by man, is not on purpose, and because of injustice and hate, or with intent to annoy and insult to the wife; but also external factors and obstacles such as illness or imprisonment, or... have been caused that man becomes disable from performing his duties.

In such cases, if the issue lasts so much that a woman experiencing distress and constriction, the court on the basis of Article 1130 of the Modified Civil Code can decide to divorce for the wife (Emami, 1997, p. 35).

Some lawyers believe that "this idea is fair in terms of respect for the mode of wife, but it will be difficult to accept it, because according to the general principles of commitments, wherever that the external event is a barrier from carrying out the commitment and its disposal is out of the ability of the man, not making the commitment cannot be attributed to him; and for this reason also committed is exempt from compensation for the loss due to not to make the commitment.

So it should not be claimed that if a man because of damage in battle or captivity in the camp of the enemy could not have intercourse with his wife for a long time then he has not fulfilled his tasks. 


\subsubsection{Communication Abuse and Ill-Treatment of Husband to Wife}

This case due to the disobedience of man can be one of the causes of divorce to the woman's request that it is also included in paragraph 2 of Article 1130 of the Civil Code before the reform. But after the reform that was taken place in this article, Communication abuse of husband was raised as an example of distress and constriction in the life of a wife. A husband who has communication abuse with his wife in life, if his ill-treatment is not accidental and fleeting, the woman can refer to the religious judge and request for divorce because of distress and constriction and adversity in life; and the religious judge even forces the husband to divorce and if he refused, he himself makes the wife divorced. It should be noted that man and woman who have grown up in two different families willingly or unwillingly differ in some of their tastes, especially in the early years in life and may have conflict with each other, but judge can break the marriage in a case that the treatment abuse of husband is as much that life continuing is intolerable for a wife. On the other hand, some lawyers believe: "If communication abuse is associated exclusively by women, interpretation of this article cannot be used for divorce" (Emami, 1997, p. 37). And "if the court ascertains that the main cause of difference between husband and wife had been the ill- treatment of wife and her inappropriate behavior led to irritability of the husband, this fact can be known effective in assessing the reasonableness of fight and condemning the wife Especially when it is identified that measure of wife has been intentional and has been done to provide the grounds for divorce" (Katoziyan, 1997, p. 404).

\subsubsection{Infectious and Incurable Disease}

In the marriage contract, there is something called imperfections cause to terminate the marriage contract due to some defects that appear in husband or wife and the parties will have the right to terminate the marriage contract and divorce do not need to do rituals and ceremonies of divorce. Including blindness of both eyes, Invalidism, leprosy or Hansen which is both communicable disease and many scholars believe that in the case of these diseases in the woman, the husband will have the right to terminate the marriage contract; and Article 1123 of the Civil Code also refers to this issue.

These two diseases are not exclusive to women and men may also be affected. In addition, if the woman is suffering from this sickness, she can easily be divorced by her husband, but if the man is suffering from leprosy or Hansen woman has no alternative, while in the former way she should have the right to terminate the marriage contract. Although some Jurisprudents including Shahid Sani (Shahid Sani, p. 380) (Qods ravine (Sharif) has accepted this idea).

On the other hand, a number of lawyers to Article 1130 of the Civil Code make some bugs in this relation that this article with all its advantages, but the patient's status has not taken into account.

So they say: "In some diseases, especially those have psychological roots, divorce can make worse the patient's condition and sometimes kill the patient. In such cases the fair dictates that the danger of marriage life for sick wife and the risk of divorce to be compared to her and If the court agrees with the divorce that there is no other choice to protect the health and life of claimed person" (Katoziyan, 1997, p. 404).

\subsubsection{Male Infertility and Other Complications That Prevents the Birth and Reproduction}

Birth and reproduction is one of the main goals of forming a family, and after passage the first months of marriage and the passage of passion and vitality of it, usually people search immortality of their name and their memory in their children and therefore very infrequently occurred that a man proposes infertility female to the and very rarely happens that a woman although with knowing the infertility of her suitor answers affirmatively. Therefore, if the infertility of man makes the life together with the distress and constriction then the woman can request for divorce. However, infertility is not by itself the pretext of separating from husband. Perhaps women whose husbands are infertile but they also have old age or illness and cannot have a child. In such cases, infertility cannot be considered a cause for divorce.

Sometimes the husband and wife both are healthy and they have the ability to have children, but for various reasons do not have children together or do not agree with each other or one of them is the barrier of birth. In such cases, in case of distress and constriction, a woman has the right to request divorce of the court. Some people know the refusing of man to have a child and indifference to enthusiasm of mother as a kind of treatment abuse, that it is incompatible with good companionship of man, "a husband who refuses to have a child in illegitimate excuses or with intent to annoy his wife has been committed the communication abuse and if the requirement of the husband to a pregnant woman is not effective and continue the life is with intolerable distress in this case it must be said however that forbearance to virtue is not possible, there is no choice but to free the woman to the beneficence" (Ibid, p. 418). 


\subsubsection{Leave Family Life by Man}

If the husband is absent person, it is subject to specific provisions that they mentioned in Article 1029 of the Civil Code, however, Leave family life is related to the case that a man deliberately leaves his common life with his wife and children. Whether there is no news of him or take live so that family members see him every day. So if someone in natural disasters, such as war, hijacking and exile stays away from his family, it cannot be said that he has left the family. When also a spouse travels for treatment or as well as for trade and his absence would not be long enough that it can be said that he has sacrificed the family life for other reasons, cannot be a cause for divorce. Anyway "leaving family life alone cannot be considered a cause for divorce, and often if it is with other effects such as non-payment of alimony and not to fulfill the specific marital duties and causes distress and constriction for women, it can be considered one of causes to divorce. In fact result of leaving family life means distress and constriction of wife would cause the divorce and it is one of the examples of the implementation of the rule of negation the distress and constriction" (Ibid, p. 414).

Because "someone might leave the family life through various missions and travels to other countries and in this period by paying all the costs of family life, keep his family on welfare in order to not to put them in constriction. Obviously, this leaving cannot be considered as a cause to divorce" (Tabatabai Yazdi, p. 105).

\subsubsection{Have Other Spouse on Behalf of a Husband}

Another case is that in a second marriage, the husband may act in two ways:

A - He remarries with the permission of the court.

B - He arbitrary remarries.

In the first case, "it is assumed that the loss of preventing the marriage to the husband and the stability of a family is harder and more than the loss for the first wife. The court also ascertains financial ability of man and the possibility of implementing the justice on his behalf until the woman has no difficulty. But in the second case, it is possible that only license of his work is sensuality. So it is natural to say that in such cases, that woman cannot tolerate the marriage life, she can request for divorce of court and gets rid of the trap that her husband made for her. But In these cases, whether the court's permission is taken or the husband marries without the permission of the court, his re-marriage is not grounds for divorce, but the potential distress and constriction that are created by this action for a woman can be a document for divorce. Of course, any number of marriages do not make the life hard and unbearable. Some women, especially in rural areas, know it's a natural thing and the rights of man and get along with it with the consent or reluctant (Katoziyan, 1997, p. 393). So, the court must meet distress and constriction for resorting to Article 1130 of the Civil Code.

\subsubsection{Unfairness in the Conduct with Wives}

"Justice, is meant equality. It is a virtue which whereby that ant thing that is the right of anyone should be granted them and in the relationship of a husband with his wives, justice is used in the same concept.

The husband should behave in giving alimony and how to communicate with them in a way that each one finds herself equal with another one. The injustice of husband in communication with his wives is a special face of behavior abuse that occurs in this assumption because the need for good communication with each of the women is this that they are not humiliated in front of each other. Another point is that only discrimination between women will not be on the grounds for divorce, but also possible distress and constriction of it allows the woman the right to end her excruciating life and requests for relief. And in case of continuing injustice, the court first forces the husband to execute the justice and in case of impossibility of justice, divorce will be used as last drug" (Ibid, p. 402).

\subsubsection{Definitive Sentence to Long Imprisonment}

Long imprisonments cause the disruption of the family basis. Wife and children of prisoners remain orphan and without any help and sometimes also their livelihoods fall into poverty; and "even some Jurisprudents such as Seyyed Mohammad Kazem Tabatabai about a woman whose husband has been sentenced to life imprisonment gives the right to request for divorce of judge and ruler" (Tabatabai Yazdi, p. 75).

But what is withdrawn of Article 1130 of the Civil Code is this, "that it does not have a necessity that the imprisonment of husband is permanent, but also if his imprisonment takes as long as on that the rest of life for women is intolerable and in particular where that deviation fear and guilt is possible the court can compel the husband to divorce. 


\subsubsection{Committing the Offense against Family Honor and Dignity of Wife}

If the crime of man, causes the humiliation of women in society and in practice, tolerate such a situation is difficult for her, she can ask the court for divorce. "If a husband deliberately or by mistake goes in a way that is incompatible with the dignity of his wife and family, the woman can accept the situation patiently or puts an end to their marriage and lives separately. A cause of divorce in this assumption is the effects of an event that was happened in the past and continues until today and it is the embarrassment caused by the crime of man.

\section{Negation of Distress and Constriction in Deals}

Insolvent exemption of the role of religion until the time of fixing his solvency is including major effects of the negation rule of distress and constriction in deals. Documentary of this verdict is verse 280 of Surah Baqarah that says:

《هر

(The Holy Quran, Surah Baqarah, verse 280) and consensus of Muslims

Someone who is unable to pay his debt due to insolvency, after fixation the insolvency, means his inability of repayment of the debt, is left free and housing, clothing, and essential life things suitable with his status remains for him as exceptions of debt and does not have to sell them to pay the debt or submit to creditors. Some believe if the insolvent is profession or business owner, the creditor can appoint him to work and if the rest of his salary is more than his spending and family income, and it is customary, the creditor can obtain it of him as the quest. A religion that is subject to this rule whether it is the origin of that transaction, or compulsory liability and legal financial obligations such as alimony of relatives, Mahr, custody remuneration and others there are several laws about the debtor solvency or the person who is required to pay property in Iranian rules: Article 277 of the Civil Code states that "... the judge can determine the payment deadline or law and time of loans owe according to the state of the debtor or "and an Article 652 stipulates mentioned law about the loan:

"The judge, according to the circumstances determines the time or loans for debtor at the time of demand.

Article 229 of the Civil Code stipulates in this regard: "if committed by an event that its disposal is beyond the scope of his authority fails to meet his obligation will be condemned to pay damages." Article 387 of the mentioned law about termination of the contract of sale in the form of loss of sales beside the vendor without fault and his negligence and articles 481 and 483 of the same act about canceling the contract of rent in the case of going out the tenant of the potential of profit or whole or in part loss of it by the incident is one of the examples of the rule of the discussed issue.

Article 229 of the Civil Code is related to the case that is impossible to fulfill the commitment due to Tari incident, but about the case that fulfill the commitment is not impossible, but it will be as much difficult that is not able to implement it except for tolerating huge losses, the Iranian Civil Code is static but In the laws of some countries, including Egypt's Civil Code, revise such transaction has been anticipated by the judge.

This sentence that has been adapted by European rules, although it has been alleged its base is on the interpretation of the will of the parties of the transaction, it is not compatible in terms of problem solving method with accepted principles of Islamic law, including the need to compromise for the accuracy of transactions. Terminate the transaction in this case is closer to justice.

\section{Negation of Distress and Constriction in Rental Relations}

Another case that the provisions of rule of distress and constriction have been applied in the law is related to the rental relations between landlord and tenant which the legislator in Article 9 of the Landlord and Tenant Act, adopted on 02.04.1983 has been provided:

"In cases that a court eviction from a rental land in terms of shortage the housing knows as a cause of distress and constriction for the tenant, it is not the conflict with distress and constriction of the landlord, the judge can set the deadline for the tenant (Set of legal laws and regulations, 1991, p. 668).

The landlord can demand for discharge if the time of rent finishes on the principle of monarchy rule based on the initial rules:

(الناس مسلطون علي امو الهم)

And the landlord cannot be forced to rent and therefore the court gives the sentence of eviction.

Now if distress and constriction are created for the tenant on the basis of the sentence of eviction, hear the eviction sentence if prevented according to the rule negation of distress and constriction. Of course, if the stop the eviction sentence caused distress and constriction for the owner, the rule will not implemented for the tenant. 
Because with rule negation of distress and constriction that is the current on the side of the owner, rule negation of distress and constriction on the side of the tenant is ineffective. This is not because of conflict or interfere, but it is also because that by implementation of distress and constriction rule on the side of tenant, distress and constriction is created for owner and distress and constriction become ineffective with the implementation the rule in the side of the owner and this means that the object becomes cause for its absence.

(يلزم من وجوده عدمه)

And this is impossible (Mousavi Bojnordi, 2003, p. 15).

"In cases that the court identifies the sentence of discharging of the training places due to lack of proper place the cause of distress and constriction, the court is obliged to meet the distress and constriction, refrains of issue the sentence for a period of five years and this law is enforceable from the date of the approval date" (Ibid, p. 671).

\section{Negation the Distress and Constriction in International Laws}

Theory as "theory of change of circumstances" or "Theory of unforeseen events" is raised in International laws and also domestic laws in many countries that is remarkably similar to rule negation of distress and constriction in Islamic laws and jurisprudence that compares it with rule negation of distress and constriction seems beneficial.

According to this theory, when because of an unpredicted non-fixing and avoidance event, bilateral trade balance has been obviously disturbed and, therefore, the implementation the provisions of the contract becomes difficult, mentioned contract shall be adjusted by the judge if it is possible or the case is dissolved. This theory has its roots in Roman laws and it is based on the principle of «rebuses sic stantibus» and attributed to "St. Thomas Daken".

This theory has not been still included in domestic law of all countries in legal form, but because in fact it is born out of intense economic development of recent industry ages, it has penetrated in some conventions relating to international treaties and laws or legal precedent of some countries; So that In the Article 61 of the Vienna Convention related to the Treaties in 1966 has brought: "If the circumstance existing at the time of the contract, is the basis of the agreement and the mutual consent of the parties and this radical transformation be affected In the territory of obligations that must be implemented by treaty this change of circumstances will be effective in the contract.

Also in accordance with Article 373 of the Swiss commitments: "If in the event of unconventional conditions that it is not predicted for the parties, enforcement action becomes impossible or extremely difficult, the judge can increase the specified price or agree to terminate the contract at his/her discretion.

In Article 269 of the Civil Code abolished in 1933 in Poland also was stated: "If in the result of exceptional events such as war, epidemics and an overall waste of product and other natural disasters, implementation of obligations arising from contracts encounters with too much difficulty and imposes the heavy loss to the one side of the parties, so that at the time of concluding the contract is not foreseen by any of the parties, the judge is allowed to determine the method of implementing the provisions of the contract and the rate of its importance and even cancels the contract according to the principle of good faith by taking into account the interests of the parties of the contract. In articles of 1467 to 1469 of the Italian Civil Code also have been enacted similar regulations.

In some countries where in their law have been not anticipated such regulations, Judicial procedures tend to respect this theory; As in France before the adoption of Regulations of September 30, 1953, regarding the leasing of business affairs and the law 11 of March, 1957, relating to the ownership of literary works and artistic works, such tendency was evident in the judicial procedure. But because of opposition from the Supreme Court precedent with this tendency has not definitively accepted this theory.

Despite this the State Council of France accepts the theory of unforeseen incidents about claims related to the public service; as due to the decision of dated March 13, in 1916 this council in fights of municipality against a gas distribution company that was related to the sudden and unexpected events of war and a huge increase in coal prices, voted in favor of the company by taking into consideration the difficulty and complexity of implementing the company's commitment in the gas distribution in rates approved by the municipality.

\section{Conclusion}

Jurisprudential rules are rules that are occurring on the way to gain divine religious commandments, but this use was not about inference and mediation but also it is about implementation.

The aim of this research had been the investigation of the common jurisprudential rules of Iranian civil law with 
an emphasis on (rule of no loss, negation of distress and constriction and beneficence).

These rules, due to its economic and social broad use traditionally, had been one of the most basic Islamic jurisprudence rules. A variety of jurisprudential rules common in Iranian civil law contain Iodine and capture rule, iodine liability rule, pride, distress and constriction, dissipation, correction, respect for the property of the people, the monarchy on the properties, no loss rule and more. These rules are famous and valid rules that are used widely in most juristic and legal issues and the axis of many everyday transactions. In this study, we got the following results:

1- First, the word "no" in no loss sentence is the no of negation and not the no of denial.

Secondly, it is not dedicated to personal loss, but a generic loss is contained as well.

2-Thirdly, the rules of Islam, including task and situation - are based on negation a public and generic loss and basic commandments of Islam, In general, the principles mean the lack of public loss is observed and also any adverse action is at the signing of the religious judge in social relations.

3- Negation of distress and constriction is a general rule that Jurisprudents have referred to it in many cases, and thereby, they have passed a sentence to the negation of tasks which are required the distress and constriction for oblige. To cite this rule, does not allocate to the certain field of fields of jurisprudence, but also has been invoked in the different topics, ranging from worships and transactions. The common points are seen between two mentioned rules that were extracted by Shia and Sunni jurists and have been used in the line of jurisprudential rules. Their main commonality is in the using the Quran as an essential resource for proving the mentioned rule. Another commonality of them is that both of them are keys to changing legal issues that it is based on the Islamic jurisprudence dynamic prudence and have been used extensively in contemporary Islamic societies. These rules have entered into law in some cases, and they have caused modern legal developments in resolving most of the problems that have been emerged due to adhere to the general principles and rules and dry and lifeless public rules and with low flexibility.

4- Islamic jurists do not dispute in principle and no guarantee based on beneficence, however, about there are discussion and dialogue about the nature of beneficence and charity and limits of beneficence rule.

\section{References}

Ameli, H. (1993). Shiyatoal Vasayel (Vol. 8). publishing of Tehran.

Emami, H. (1997). Civil Rights (3rd ed.). Tehran, Islamiyah publishing.

Katoziyan, N. (1997). general rules of contracts (2nd ed., Vol. 8). publishing holding company.

Shahid sani, Zinealdin, Alrozatol Albahyeh in description of lameh aldameshghiyeh, volume 2, Second Edition daro al ehya of Arabic Altrath, Beirut, Bita.

Tabatabaie Yazdi, Seyed Mohammad Kazem. Takamalt Alorvatol Vosgha, vol. 1, Bita.

The Holy Quran.

The set of legal laws and regulations. (1991).

\section{Copyrights}

Copyright for this article is retained by the author(s), with first publication rights granted to the journal.

This is an open-access article distributed under the terms and conditions of the Creative Commons Attribution license (http://creativecommons.org/licenses/by/4.0/). 